\title{
Electron Microscopic Radioautographic Study on DNA Synthesis of Mitochondria in Adrenal Medullary Cells of Aging Mice
}

\author{
Tetsuji Nagata ${ }^{*}, 1,2$ \\ ${ }^{1}$ Department of Anatomy and Cell Biology, Shinshu University School of Medicine, Matsumoto, 390-8621 Japan \\ ${ }^{2}$ Department of Anatomy, Shinshu Institute of Alternative Medicine, Nagano, 380-0816 Japan
}

\begin{abstract}
For the purpose of clarifying the aging changes of DNA synthesis of mouse mitochondria in adrenal medullary cells, 10 groups of aging mice, each consisting of 3 individuals, total 30, from fetal day 19 to postnatal newborn at day 1 , $3,9,14$, adult at month $1,2,6,12$ and 24, were injected with ${ }^{3} \mathrm{H}$-thymidine, sacrificed $1 \mathrm{hr}$ later and the adrenal tissues were fixed and processed for electron microscopic radioautography. On electron microscopic radioautograms obtained from each animal, number of mitochondria and the number of labeled mitochondria labeled with silver grains due to ${ }^{3} \mathrm{H}$ thymidine showing DNA synthesis in each adrenalin cell and noradrenalin cell were counted and the results of labeling indices in respective developing groups were compared respectively.

From the results, it was demonstrated that the numbers of mitochondria in both adrenalin and noradrenalin cells in the adrenal medullae of mice at various ages increased from fetal day 19 to postnatal month 6 due to aging of animals, respectively, and decreased to month 24 , while the number of labeled mitochondria and the labeling indices of intramitochondrial DNA synthesis incorporating ${ }^{3} \mathrm{H}$-thymidine increased from fetal day 19 to postnatal day 14 (2 weeks), reaching the maxima, and decreased to month 24 . It was shown that the activity of intramitochnodrial DNA synthesis in the adrenal medullary cells in aging mice increased and decreased due to aging of animals.
\end{abstract}

Keywords: Mitochondria, mouse adrenal medulla, EM radioautography, DNA synthesis, aging.

\section{INTRODUCTION}

Intramitochondrial nucleic acid syntheses, both DNA and RNA, in mammalian and avian cells were first demonstrated morphologically by the present author by means of electron microscopic radioautography with accurate localization in primary cultured cells of the livers and kidneys of mice and chickens in vitro $[1,2]$ and then in some other established cell lines such as HeLa cells [3-6] or mitochondrial fractions prepared from in vivo cells [7-9]. It was later commonly found in various cells and tissues not only in vitro obtained from various organs in vivo [10-14], but also in vivo cells of various organs such as the salivary glands [15], the liver [16$29]$, the pancreas $[30,31]$, the trachea [32], the lung [33], the kidneys [34], the testis [35,36], the uterus [37,38], the adrenals [39-41], the brains [42], and the retina [43-47] of mice, rats and chickens. The relationship between the intramitochondrial DNA synthesis and cell cycle was formerly studied and it was clarified that the intramitochondrial DNA synthesis was performed without nuclear involvement [3]. However, the relationship between the DNA synthesis in the adrenal cells and the aging of individual animals has not yet been clarified. We have studied the relationship between the DNA synthesis in the adrenal cortical cells and the aging of individual animals from perinatal to adult in aging and senescence up to postnatal month 24 (2 years) [48]. However, the relationship

*Address correspondence to this author at the Department of Anatomy and Cell Biology, Shinshu University School of Medicine, Matsumoto, 3908621 Japan; Tel: +81-263-46-2848; Fax: +81-262-33-0591;

E-mail: nagatas@po.cnet.ne.jp between the DNA synthesis in the adrenal medullary cells and the aging of individual animals was only formerly published in a previous report on young adults at postnatal month 6 [49], while further study on aged and senescent adults has not yet been completed. This paper deals with the relationship between the DNA synthesis in adrenal medullary cells of mice at various aging stages from fetal day 19 to postnatal newborn, juvenile, young and aged senescent adults up to postnatal month 24 ( 2 years) by means of electron microscopic radioautography as a part of our serial studies on special cytochemistry [50] and radioautographology [51].

\section{MATERIALS AND METHODS}

\section{The Experimental Animals}

The adrenal tissues were obtained from 10 groups of developing and aging normal ddY strain mice, each consisting of 3 individuals, total 30, from fetal day 19 to postnatal newborn at day $1,3,9,14$, young adults at month $1,2,6$, aged senescent adults at month12 (1 year) and 24 (2 years), each consisting of 3 litter mates of both sexes. The embryonic age was based on observation of the vaginal plug of the female mice (vaginal plug=day 0). All the animals were housed under conventional conditions and bred with normal diet (mouse chow Clea EC2, Clea Co., Tokyo, Japan) with access to water ad libitum in our laboratory. They were administered with ${ }^{3} \mathrm{H}$-thymidine, a DNA precursor, and the adrenal tissues were fixed and processed for electron microscopic radioautography. All the procedures used in this study concerning the animal experiments were in accordance 
with the guidelines of the animal research committee of Shinshu University School of Medicine as well as the principles of laboratory animal care in NIH publication No. 86-23 (revised 1985).

\section{Procedures of Electron Microscopic Radioautography}

All the animals were injected intraperitoneally with ${ }^{3} \mathrm{H}-4-$ thymidine (Amersham, England, specific activity 877 $\mathrm{GBq} / \mathrm{mM}$ ) in saline, at 9 a.m., one hour before sacrifices. The dosage of injections was $370 \mathrm{KBq} / \mathrm{gm}$ body weight. The animals were perfused at 10 a.m., one hour after the injection, via the left ventricles of the hearts with $0.1 \mathrm{M}$ cacodylate-buffered $2.5 \%$ glutaraldehyde under Nembutal (Abbott Laboratories, Chicago, ILL, USA) anesthesia. The right adrenal glands were taken out, excised and 3 small pieces of the adrenal tissues $(1 \mathrm{~mm} \times 1 \mathrm{~mm} \times 1 \mathrm{~mm})$ were immersed in the same fixative at $4^{\circ} \mathrm{C}$ for $1 \mathrm{hr}$., followed by postfixation in $1 \%$ osmium tetroxide in the same buffer at $4^{\circ} \mathrm{C}$ for $1 \mathrm{hr}$., dehydrated in graded series of ethanol and acetone, and embedded in epoxy resin Epok 812 (Oken, Tokyo, Japan).

For electron microscopic radioautography, semithin sections at $0.2 \mu \mathrm{m}$ thickness, thicker than conventional ultrathin sections in order to shorten the exposure time, were cut in sequence on a Porter-Blum MT-2B ultramicrotome (Dupont-Sorvall, Newtown, MA, USA) using glass knives. The sections were collected on collodion coated copper grid meshes (VECO, Eerbeek, Netherlands), coated with Konica NR-H2 radioautographic emulsion (Konica, Tokyo, Japan) by a wire-loop method [30-53]. They were stored in dark boxes containing silica gel (desiccant) at $4^{\circ} \mathrm{C}$ for exposure. After the exposure for 10 months, the specimens were processed for development in freshly prepared gold latensification solution for $30 \mathrm{sec}$ at $16^{\circ} \mathrm{C}$ and then in fresh phenidone developer for 1 min at $16^{\circ} \mathrm{C}$ in a water bath, rinsed in distilled water and dried in an oven at $37^{\circ} \mathrm{C}$ overnight, stained with lead citrate solution for $3 \mathrm{~min}$, coated with carbon for electron microscopy. The electron microscopic (EM) radioautograms (RAG) were examined in a JEOL JEM-4000EX electron microscope (JEOL, Tokyo, Japan) at accelerating voltages of $400 \mathrm{kV}$ for observing thick specimens.

\section{Quantitative Analysis of Electron Micrographs}

For quantitative analysis of electron micrographs, twenty EM radioautograms showing cross sections of adrenomedullary cells from each group, based on the electron microscopic photographs taken after observation on at least 100 adreno-medullary cells from respective animals, and at least 10 cells from respective cell types, i. e. adrenalin cells and noradrenalin cells, were analyzed to calculate the total number of mitochondria in each adreno-medullary cells, and the number of labeled mitochondria covered with silver grains by visual grain counting.

On the other hand, the number of silver grains in the same area size as a mitochondrion outside cells was also calculated in respective specimens as background fog, which resulted in less than 1 silver grain $(0.03 /$ mitochondrial area) almost zero. Therefore, the grain count in each specimen was not corrected with background fog. From all the data thus obtained the averages and standard deviations in respective aging groups were computed with a personal computer
(Macintosh type 8100/100, Apple Computer, Tokyo, Japan). The data were stochastically analyzed using variance and Student's t-test. The differences were considered to be significant at $\mathrm{P}$ value $<0.01$.

\section{RESULTS}

\section{Morphological Observations}

The adreno-medullary tissues obtained from ddY strain mice at various ages from embryo day 19 to postnatal day 30 , consisted mainly of 2 cell types, as observed by electron microscopy, i.e., adrenalin cells and noradrenalin cells, developing gradually. At embryonic day 19 (Figs. 1, 2) and postnatal day 1 (Fig. 3), the adrenal medullary cells were composed mainly of polygonal epitheloid type cells, surrounded by blood capillaries and fibroblasts. The medullary cells can be divided into 2 types by the ultrastructure of granules. Some of the medullary cells possessed many granules of medium electron density which were believed to correspond to the adrenalin granules containing adrenalin (Fig. 1), while some other cells possessed many granules of very high electron density which were believed to correspond to the noradrenalin granules containing noradrenalin (Fig. 2). However, the numbers of mitochondria found in their cytoplasm, both adrenalin and noradrenalin, were not so many. At postnatal day 1 (Fig. 3), day 3 (Figs. 4, 5) and day 9 (Fig. 6), the 2 types of cells differentiated and the numbers of granules, both adrenalin and noradrenalin granules, increased respectively. Likewise, the numbers of mitochondria also increased from prenatal day to postnatal days. At postnatal day 14 (Figs. 7, 8) to month 1 (Figs. 9, 10), month 2 (Fig. 11), month 6 (Fig. 12), month 12 (Fig. 13) and month 24 (Fig. 14), the numbers of adrenalin and noradrenalin granules as well as mitochondria increased. At postnatal month 1 and 2, the ultrastructure of 2 cell types was completely developed and the arrangements of the cells in the medulla became typical as adult tissues. Thus, the ultrastructure of the adrenal medullary cells showed changes due to development and aging at respective developmental stages.

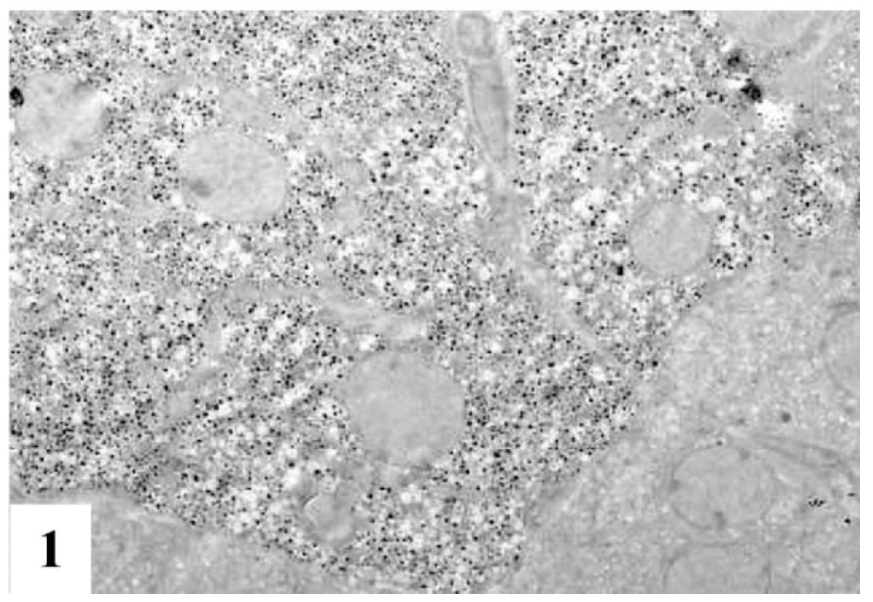

Fig. (1). Electron microscopic radioautogram of the adrenal medullary tissues of a mouse embryo at fetal day 19, labeled with $3 \mathrm{H}$-thymidine, showing DNA synthesis (several silver grains) in the nuclei as well as in a few mitochondria of 4 adenalin cells at right and 1 noradrenalin cell at left. x 3,000. (From Nagata [49]. Courtesy of J Cell Tiss Res 9: 1793-1802, 2009). 


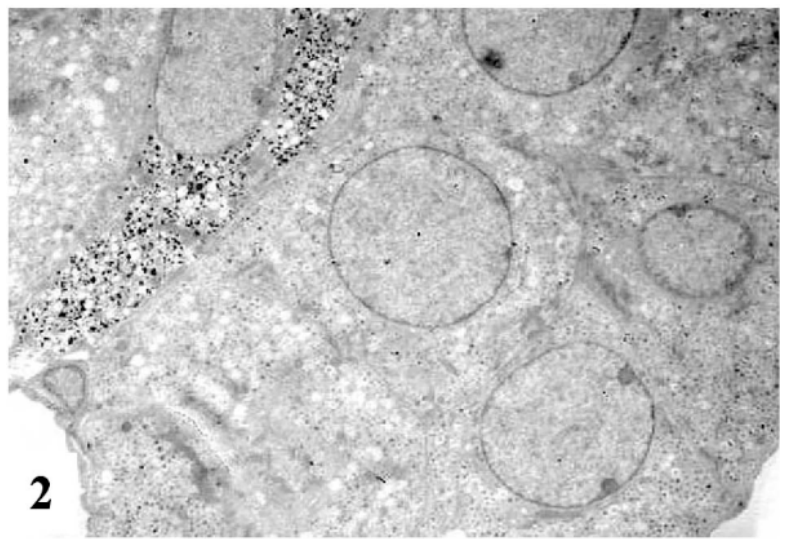

Fig. (2). Electron microscopic radioautogram of the adrenal medullary tissues of a mouse embryo at fetal day 19, labeled with $3 \mathrm{H}$-thymidine, showing DNA synthesis (several silver grains) in the nuclei as well as in a few mitochondria of 3 noradenalin cells at left and 2 adrenalin cells at right. x 3,000. (From Nagata [49]. Courtesy of J Cell Tiss Res 9: 1793-1802, 2009).

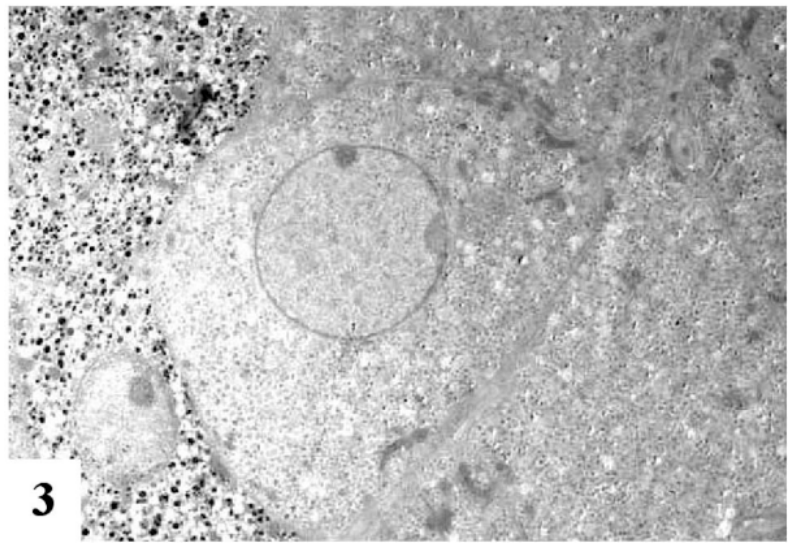

Fig. (3). Electron microscopic radioautogram of the adrenal medullary tissues of a newborn mouse at postnatal day 1, labeled with $3 \mathrm{H}$-thymidine, showing DNA synthesis (several silver grains) in the nuclei as well as in a few mitochondria of 3 adenalin cells at right and 2 noradrenalin cells at left. x 3,000. (From Nagata [49]. Courtesy of J Cell Tiss Res 9: 1793-1802, 2009).

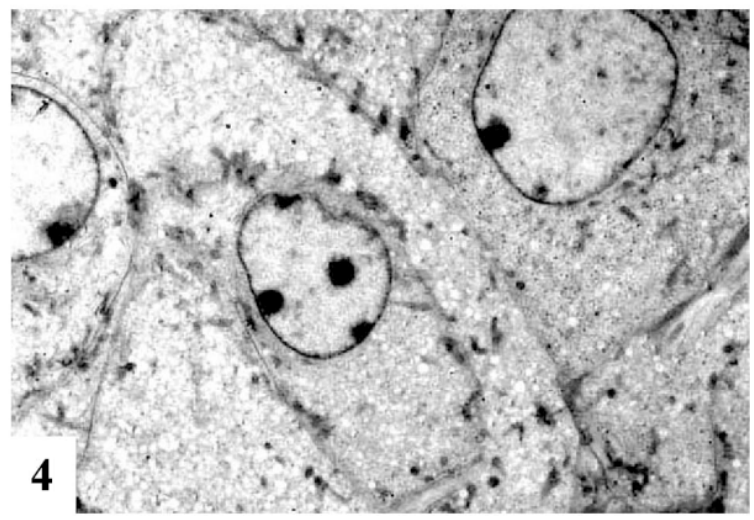

Fig. (4). Electron microscopic radioautogram of the adrenal medullary tissues of a newborn mouse at postnatal day 3, labeled with $3 \mathrm{H}$-thymidine, showing DNA synthesis (several silver grains) in the nuclei as well as in a few mitochondria of 3 adenalin cells. $x$ 3,000. (From Nagata [49]. Courtesy of J Cell Tiss Res 9: 17931802, 2009).

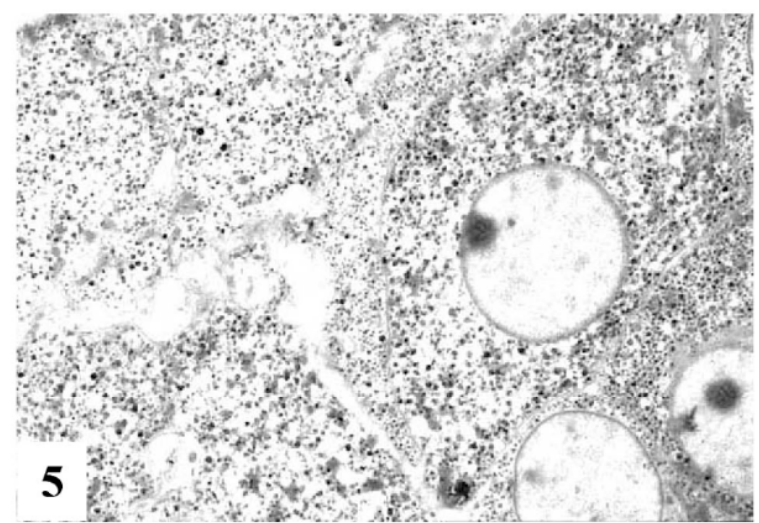

Fig. (5). Electron microscopic radioautogram of the adrenal medullary tissues of a newborn mouse at postnatal day 3, labeled with $3 \mathrm{H}$-thymidine, showing DNA synthesis (several silver grains) in the nuclei as well as in a few mitochondria of 4 noradenalin cells. x 3,000. (From Nagata [49]. Courtesy of J Cell Tiss Res 9: 17931802, 2009).

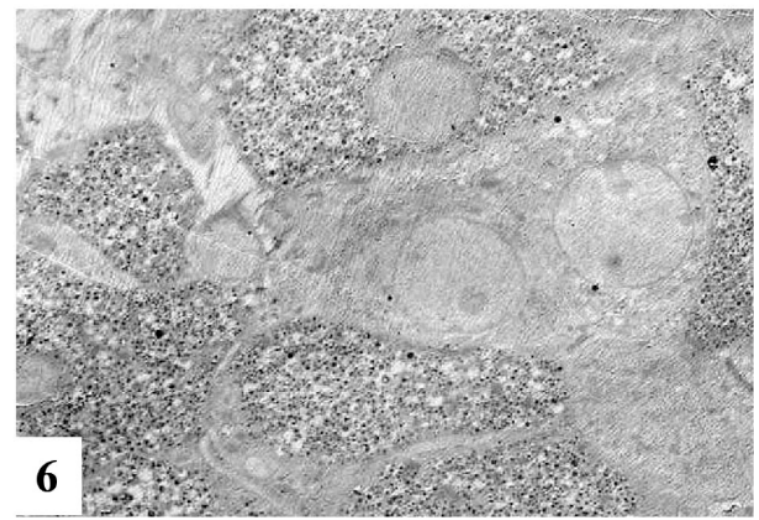

Fig. (6). Electron microscopic radioautogram of the adrenal medullary tissues of a newborn mouse at postnatal day 9, labeled with $3 \mathrm{H}$-thymidine, showing DNA synthesis (several silver grains) in the nuclei as well as in a few mitochondria of 4 noradenalin cells and 2 adrenalin cells at center. x 3,000. (From Nagata [49]. Courtesy of J Cell Tiss Res 9: 1793-1802, 2009).

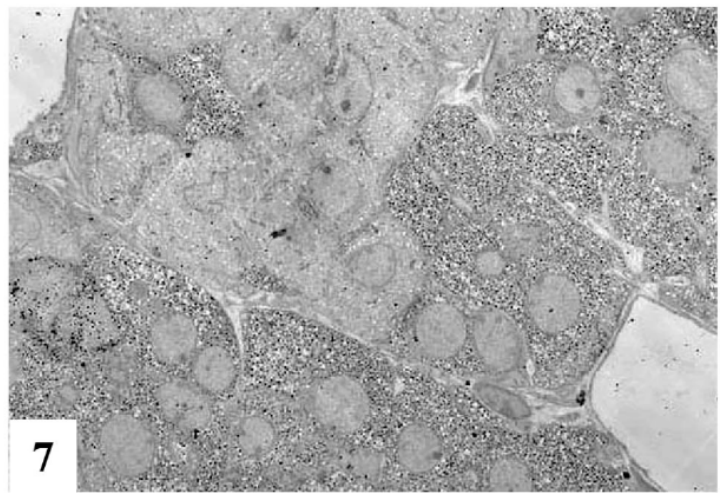

Fig. (7). Low power electron microscopic radioautogram of the adrenal medullary tissues of a juvenile mouse at postnatal day 14, labeled with $3 \mathrm{H}$-thymidine, showing DNA synthesis (several silver grains) in the nuclei as well as in a few mitochondria of 10 adrenalin cells at upper left and 15 noradenalin cells at center and right. x 1,000. (From Nagata [49]. Courtesy of J Cell Tiss Res 9: 1793-1802, 2009). 


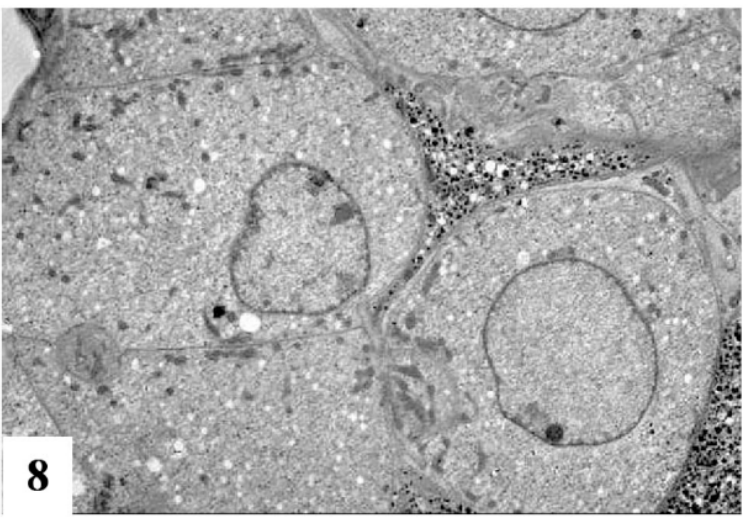

Fig. (8). High power electron microscopic radioautogram of the adrenal medullary tissues of a juvenile mouse at postnatal day 14, labeled with $3 \mathrm{H}$-thymidine, showing DNA synthesis (several silver grains) in the nuclei as well as in a few mitochondria of 4 adrenalin cells at center and 2 noradenalin cells at right. x 3,000. (From Nagata [49]. Courtesy of J Cell Tiss Res 9: 1793-1802, 2009).

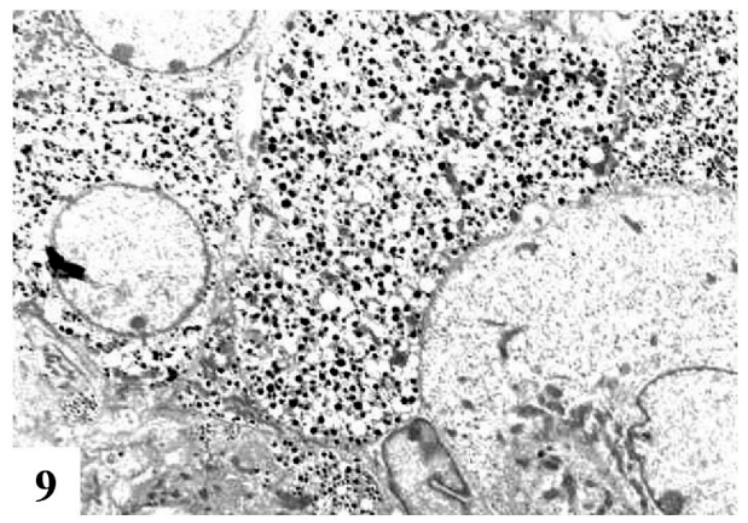

Fig. (9). Electron microscopic radioautogram of the adrenal medullary tissues of a young adult mouse at postnatal month 1, labeled with $3 \mathrm{H}$-thymidine, showing DNA synthesis (several silver grains) in the nuclei as well as in a few mitochondria of 3 adrenalin cells at bottom right, left upper and left bottom corners and 2 noradenalin cells at center. x 3,000. (From Nagata [49]. Courtesy of J Cell Tiss Res 9: 1793-1802, 2009).

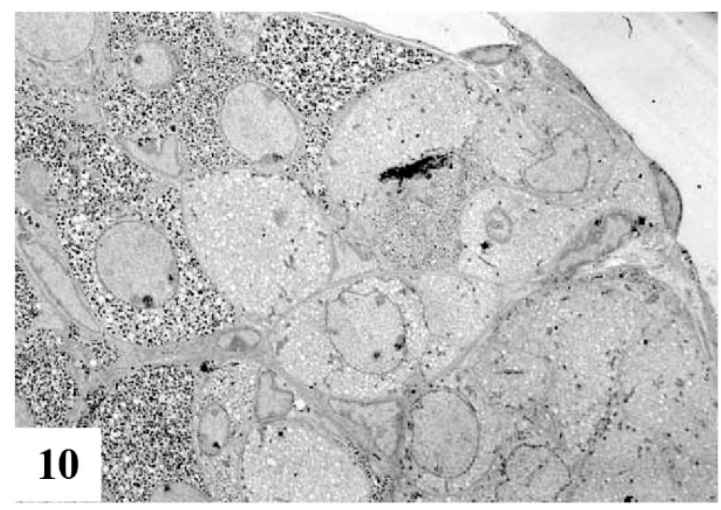

Fig. (10). Low power electron microscopic radioautogram of the adrenal medullary tissues of a young adult mouse at postnatal month 1, labeled with $3 \mathrm{H}$-thymidine, showing DNA synthesis (several silver grains) in the nuclei as well as in a few mitochondria of several adrenalin cells at bottom right and several noradenalin cells at left. x 1,500. (From Nagata [49]. Courtesy of J Cell Tiss Res 9: 1793-1802, 2009).

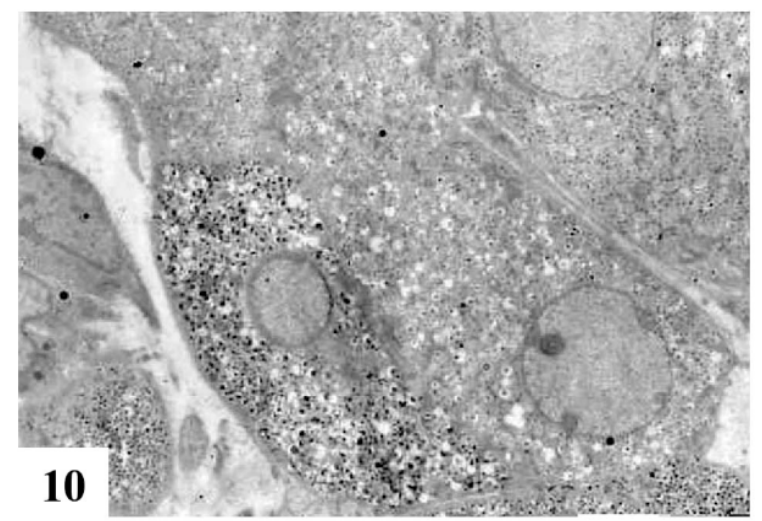

Fig. (11). Electron microscopic radioautogram of the adrenal medullary tissues of a young adult mouse at postnatal month 2, labeled with $3 \mathrm{H}$-thymidine, showing DNA synthesis (several silver grains) in the nuclei as well as in a few mitochondria of 3 adrenalin cells at upper right and 2 noradenalin cells at lower left. x 3,000. (From Nagata [49]. Courtesy of J Cell Tiss Res 9: 1793-1802, 2009).

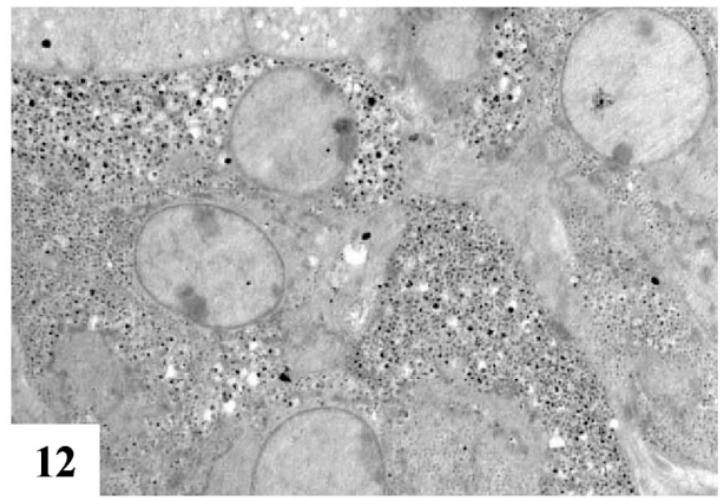

Fig. (12). Electron microscopic radioautogram of the adrenal medullary tissues of an aged adult mouse at postnatal month 6, labeled with $3 \mathrm{H}$-thymidine, showing DNA synthesis (several silver grains) in the nuclei as well as in a few mitochondria of 2 adrenalin cells at center and 2 noradenalin cells at lower left and right. $\mathrm{x}$ 3,000. (From Nagata [49]. Courtesy of J Cell Tiss Res 9: 17931802, 2009).

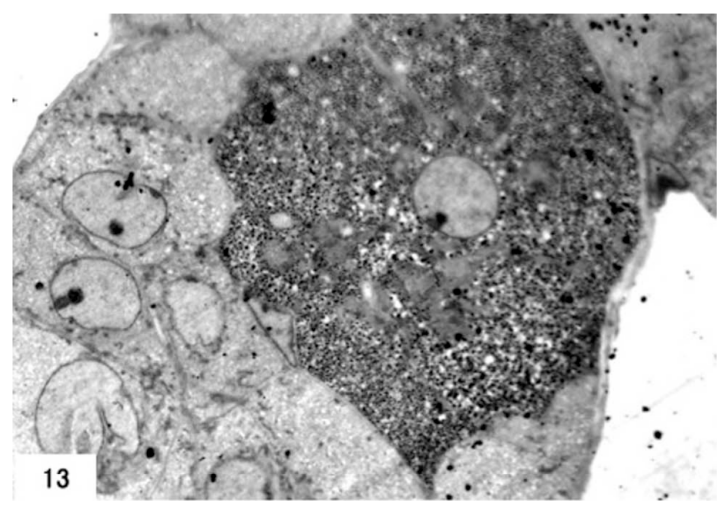

Fig. (13). Electron microscopic radioautogram of the adrenal medullary tissues of a senescent adult mouse at postnatal month 12 (year 1), labeled with 3H-thymidine, showing DNA synthesis (several silver grains) in the nuclei as well as in a few mitochondria of a noradrenalin cell at center right and several adenalin cells at left and lower left and right. x 6,000. 


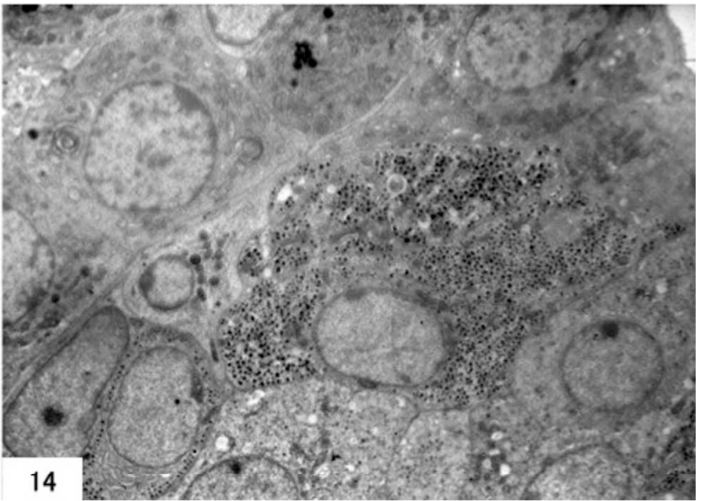

Fig. (14). Electron microscopic radioautogram of the adrenal medullary tissues of a senescent adult mouse at postnatal month 24 (year 2), labeled with 3H-thymidine, showing DNA synthesis (a few silver grains) in the 2 nuclei at lower left as well as in a few mitochondria of the noradrenalin cell at center and 2 other several adenalin cells at left and lower left and right. x 6,000.

\section{Radioautographic Observations}

Observing electron microscopic radioautograms, the silver grains were found over the nuclei of some adrenal medullary cells labeled with $3 \mathrm{H}$-thymidine, demonstrating DNA synthesis mainly in perinatal stages at embryonic day 19 (Figs. 1, 2), postnatal day 1 (Fig. 3) and day 3 (Figs. 4, 5), while less at day 9, (Fig. 6) and day 14 (Figs. 7, 8,) and adults at month 1(Figs. 9, 10), month 2 (Fig. 11) and 6 (Fig. 12), then senescent at month 12 (Fig. 13) and 24 (Fig. 14).

On the other hand, the labeled cells which showed silver grains over their mitochondria were found in all the 2 cell types, adrenalin cells (Figs. 1, 3, 4, 6-14) and noradrenalin cells (Figs. 2, 3, 5-14), at respective aging stages. In the labeled adrenal medullary cells the silver grains were mainly localized over the euchromatin of the nuclei and only a few or several silver grains were found over the mitochondria of these cells (Figs. 1, 4, 6). To the contrary, most adrenal medullary cells were not labeled with any silver grains in their nuclei nor cytoplasm, showing no DNA synthesis even after labeling with $3 \mathrm{H}$-thymidine (Figs. 1-14). Among many unlabeled adrenal medullary cells, most cells were observed to be labeled with a few silver grains over their mitochondria due to the incorporations of $3 \mathrm{H}$-thymidine especially at the perinatal stages from embryonic day 19 (Figs. 1, 2) to postnatal day 1 (Fig. 3), day 3 (Figs. 4, 5), day 9 (Fig. 6), day 14 (Figs. 7, 8), and even in adult stages at postnatal month 1 (Figs. 9, 10), month 2 (Fig. 11), month 6, (Fig. 12) month 12 (Fig. 13) and month 24 (Fig. 14), showing mitochondrial DNA synthesis. The localizations of silver grains over the mitochondria were mainly on the mitochondrial matrices but sometimes on the cristae or the inner and outer mitochondrial membranes.

\section{Quantitative Analysis}

\section{Number of Mitochondria Per Cell}

Preliminary quantitative analysis on the number of mitochondria in 10 adrenal medullary cells whose nuclei were labeled with silver grains and other 10 cells whose nuclei were not labeled in each aging group revealed that there was no significant difference between the number of mitochondria and the labeling indices $(\mathrm{P}<0.01)$. On the other hand, another preliminary analysis on the difference between the both sexes, male and female mice revealed that there was no significant difference between the both sexes. Thus, the number of mitochondria and the labeling indices were calculated regardless whether their nuclei were labeled or not as well as whether the cell belonged to male or female animal. The results obtained from the number of mitochondria in adrenal medullary cells of respective animals in 8 aging groups at perinatal stages, from prenatal embryo day 19 to postnatal day $1,3,9,14$, and month 1 , showed an gradual increase from the prenatal day 19 to

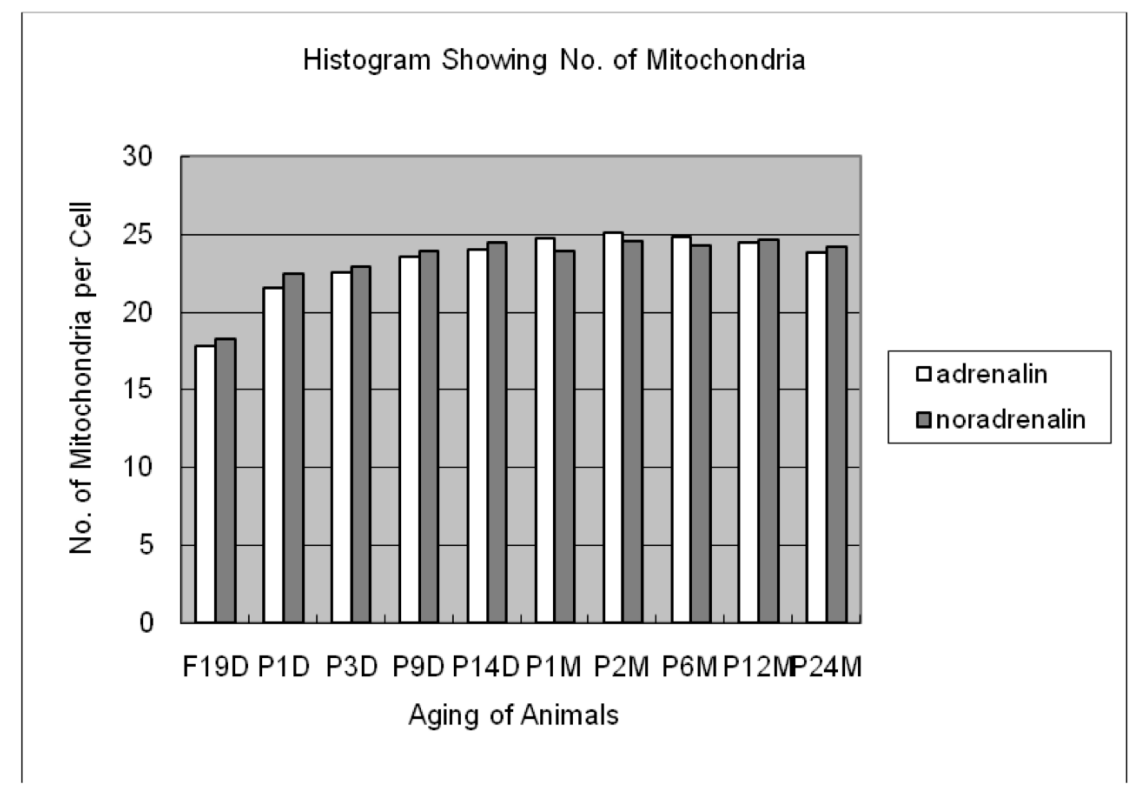

Fig. (15). Histogram showing the number of mitochondria per each adrenal medullary cell, either adrenalin cell or noradrenalin cell of respective animals in 10 groups during the development and aging from fetal day 19 to postnatal month 24 . The number of mitochondria per cell increased from perinatal stage to postnatal day 14 and to postnatal month 2, then did not change to month 24 . 
postnatal day 1 , day 3 , day 9 , day 14 , and to adult stages at postnatal month 1 , month 2 , month 6 , month 12 and month 24 as is shown in Fig. (15). The data were stochastically analyzed using variance and Student's t-test. The increases of mitochondrial numbers in both adrenalin and noradrenalin cells from embryonic day 19 to postnatal month 1 were considered to be significant at $\mathrm{P}$ value $<0.01$. To the contrary, the differences between the aged groups from month 1 to month 24 were not significant $(\mathrm{P}<0.01)$.

\section{Mitochondrial DNA Synthesis}

The results of visual grain counting on the number of mitochondria labeled with silver grains obtained from 10 adrenal medullary cells in the 3 layers of each animal labeled with 3H-thymidine demonstrating DNA synthesis in 10 aging groups at perinatal stages, prenatal embryo day 19, postnatal day 1, 3, 9 and 14, month 1, 3, 6, 12 and 24, are plotted in Fig. (16). The results demonstrated that the numbers of labeled mitochondria with $3 \mathrm{H}$-thymidine showing DNA synthesis per cell gradually increased from prenatal embryo day 19 , to postnatal day 1 , day 3 , day 9 , day 14 , reaching the maximum, and decreased to month 1 , month 2, month 6, month 12 and month 24 as shown in Fig. (16). The data were stochastically analyzed using variance and Student's t-test. The increases of the numbers of labeled mitochondria in both adrenalin and noradrenalin cells from embryo day 19 to postnatal day 14 , as well as the decreases from day 14 to month 24 were stochastically significant ( $P$ $<0.01)$.

\section{The Labeling Index}

On the other hand, the labeling indices of mitochondrial DNA synthesis in 2 cell types in respective aging stages were calculated from the number of labeled mitochondria (Fig. 16) dividing by the number of total mitochondria per cell (Fig. 15), which were plotted in Fig. (17), respectively.

The results showed that the labeling indices gradually increased from prenatal day 19 to postnatal newborn day 1 , day 3 , day 9 to juvenile stage at day 14, reaching the maximum, and decreased to adult stages at month 1 , month 2 and aged senescent stage at month 6 , month 12 and month 24 as shown in Fig. (17). From the results, the increases of the mitochondrial labeling indices in both adrenalin and noradrenalin cells from embryo day 19 to postnatal day 14 , as well as the decreases from day 14 to month 24 were stochastically significant $(\mathrm{P}<0.01)$.

\section{DISCUSSION}

From the results obtained at present, it was shown that intramitochondrial DNA synthesis was observed in adrenal medullary cells, both adrenalin cells and noradrenalin cells, of developing and aging mice at various ages from prenatal embryos to postnatal newborn, young juvenile and adult stages and the number of mitochondria per cell showed increases due to aging, while the number of labeled mitochondria per cell and the labeling indices showed increases and decreases due to aging.

As for the macromolecular synthesis in various cells in various organs of experimental animals observed by light and electron microscopic radioautography, it is well known that the silver grains due to radiolabeled ${ }^{3} \mathrm{H}$-thymidine demonstrate DNA synthesis [1, 2, 3, 50, 51]. The previous results obtained from the studies on the adrenal cortical cells of aging mice by light microscopic radioautography revealed that silver grains indicating DNA synthesis incorporating ${ }^{3} \mathrm{H}$ thymidine were observed over the nuclei of some adrenal cortical cells at perinatal stages from postnatal day 1 to day 14 [39, 40]. However, they did not observe the intramitochondrial DNA synthesis. We formerly observed the intramitochondrial DNA synthesis in the adrenal cortical

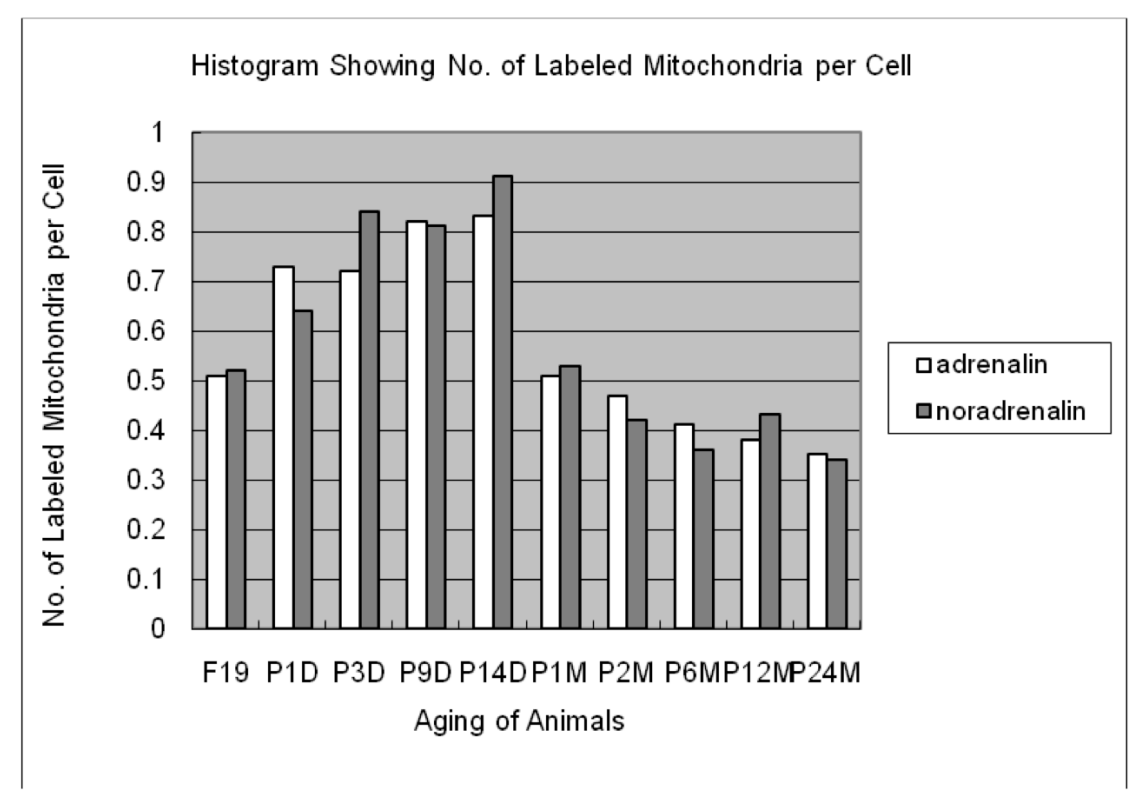

Fig. (16). Histogram showing the number of labeled mitochondria per each adrenal medullary cell either adrenalin cell or noradrenalin cell of respective animals in 10 groups during the development and aging from fetal day 19 to postnatal month 24 . The number of labeled mitochondria per cell increased from perinatal stage to juvenile stage at postnatal day 14, then decreased from adult stage at month 1 to month 24 . 


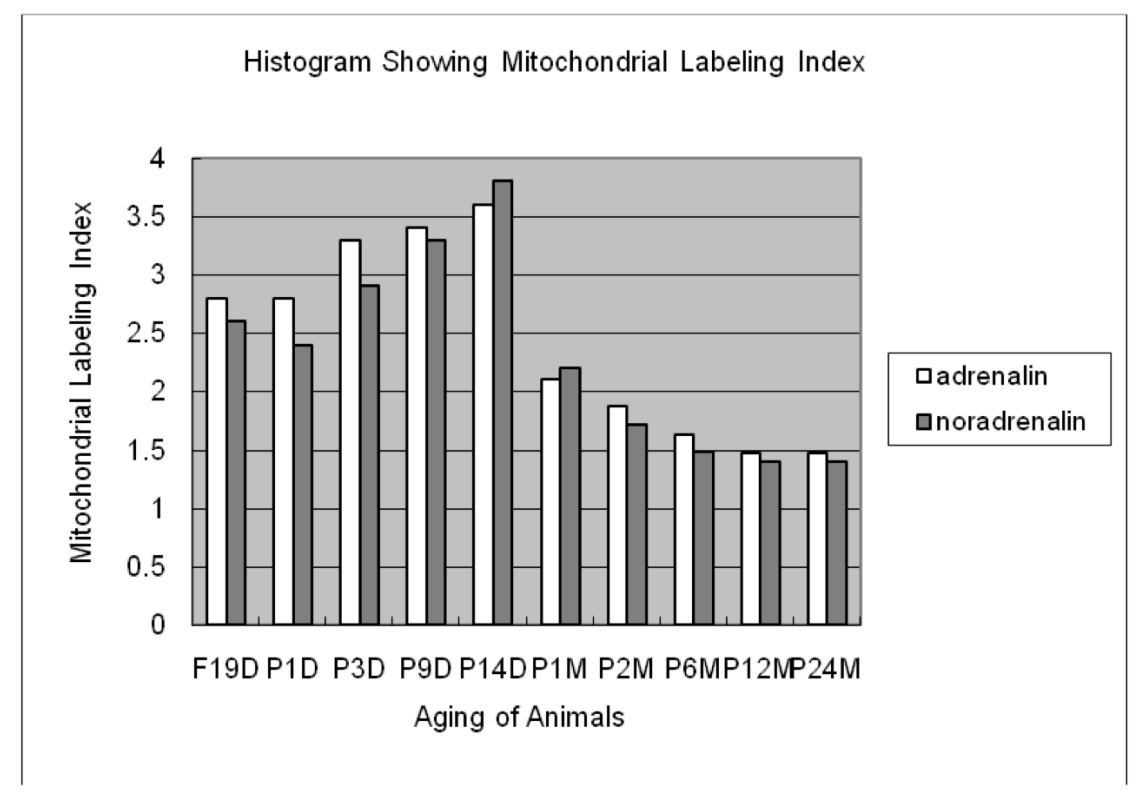

Fig. (17). Histogram showing the labeling index of mitochondria per each adrenal medullary cell in either adrenalin cell or noradrenalin cell of respective animals in 10 groups during the development and aging from fetal day 19 to postnatal month 24 . The labeling index of mitochondria increased from perinatal stage to juvenile stage at postnatal day 14, then decreased from adult stage at month 1 to month 24 .

cells of 3 layers, zona glomerulosa, fasciculate and reticularis, from perinatal stages to postnatal young adult and aged senescent adult stages [48], as well as in the adrenal medullary cells, both adrenalin cells and noradrenalin cells, at various ages from fetal day 19 to postnatal newborn day 1 , 3,9 , juvenile day 14 and to adult month 1, 2 and 6 [49]. However, the relationship between the DNA synthesis in the adrenal medullary cells of the aged and senescent adults from postnatal month 12 to 24 has not yet been clarified. We have completed the further study in the present experiment.

In the present study, the numbers of silver grains showing nuclear DNA synthesis, on the other hand, did not give any significant difference between the 2 cells types in the same aging groups. The radioautograms showing incorporations of ${ }^{3} \mathrm{H}$-thymidine into mitochondria indicating mitochondrial DNA synthesis resulted in silver grain localization over the mitochondria independently from the nuclei whether the nuclei were labeled with silver grains or not in both cell types, adrenalin and noradrenalin cells in the medullae from prenatal embryo day 19 to postnatal day 1, 3, 9 and 14, to postnatal month 1, 2 and 6, during the development and aging. The numbers of labeled mitochondria showing DNA synthesis as well as the labeling indices increased from perinatal embryonic day to postnatal newborn and juvenile stages at day 14, reaching the maxima, and then decreased to the adult stages at month 1, 2, 6 and further to the senescent stage at month 12 and 24 .

With regards to DNA in mitochondria in animal cells or plastids in plant cells, many studies have been reported in various cells of various plants and animals since 1960s [5457]. Most of these authors observed DNA fibrils in mitochondria which were histochemically extracted by DN'ase. Electron microscopic observation of the DNA molecules isolated from the mitochondria revealed that they were circular in shape, with a circumference of 5-6 $\mu \mathrm{m}$ [58]. It was calculated that such a single molecule had a molecular weight of about 107 daltons [59]. Mitochondria of various cells also contained a DNA polymerase, which was supposed to function in the replication of the mitochondrial DNA [60]. On the other hand, the incorporations of ${ }^{3} \mathrm{H}$-thymidine into mitochondria demonstrating DNA synthesis were observed by means of electron microscopic radioautography in lower organism such as slime mold [61, 62], tetrahymena [63] or chicken fibroblasts in tissue culture under abnormal conditions [64]. However, these authors used old-fashioned developers consisting of methol and hydroquinone (MQdeveloper) which produced coarse spiral silver grains resulting in inaccurate localization over cell organelles when observed by electron microscopy. All of these authors showed photographs of electron radioautographs with large spiral-formed silver grains $(2-3 \mu \mathrm{m}$ in diameter) localizing not only over the mitochondria but also outside the mitochondria. In order to obtain smaller silver grains, we first used elon-ascorbic acid developer after gold latensification [1-6], which produced comma-shaped smaller silver grains (0.4-0.8 $\mu \mathrm{m}$ in diameter), then later we used phenidon developer after gold latensification, producing dotlike smaller silver grains (0.2-0.4 $\mu \mathrm{m}$ in diameter) localizing only inside the mitochondria showing ultrahigh resolution of radioautograms [30, 50-53]. These papers were the first which demonstrated intramitochondrial DNA synthesis incorporating ${ }^{3} \mathrm{H}$-thymidine with accurate intramitochondrial localization in avian and mammalian cells. With regards the resolution of electron microscopic radioautography, on the other hand, many authors discussed the sizes of silver grains under various conditions and calculated various values of resolutions [4,5,62-67]. Those authors who used the M-Q developers maintained the resolution to be $100-160 \mathrm{~nm}[65$, $66]$, while those authors who used the elon-ascorbic acid developer $[4,5,67]$ calculated it to be $25-50 \mathrm{~nm}$. When we used phenidone developer at $16^{\circ} \mathrm{C}$ for 1 min after gold latensification, we could produce very fine dot-shaped silver grains and obtained the resolution around $25 \mathrm{~nm}[30,50-53$, 
68]. For the analysis of electron radioautographs, Salpeter et al. [65] proposed to use the half-distance and very complicated calculations through which respective coarse spiral-shaped silver grains were judged to be attributable to the radioactive source in a certain territory within a resolution boundary circle. However, since we used phenidone developer after gold latensification to produce very fine dot-shaped silver grains, we judged only the silver grains which were located in the mitochondria which were dot-shaped very fine ones to be attributable to the mitochondria without any problem as was formerly discussed [3-5, 50-53].

Then we also demonstrated intramitochondrial DNA synthesis incorporating ${ }^{3} \mathrm{H}$-thymidine in some other established cell lines originated from human being such as HeLa cells [3-6] or mitochondrial fractions prepared from in vivo mammalian cells such as rat and mouse [7-9]. It was later commonly found in various cells and tissues not only in vitro obtained from various organs in vivo such as the cultured human HeLa cells [13, 69], cultured rat sarcoma cells [12], mouse liver and pancreas cells in vitro [11, 14, 31 ], but also in vivo cells obtained from various organs such as the salivary glands [15], the liver [16-29], the pancreas $[30,31]$, the trachea [32], the lung [33], the kidneys [34], the testis $[35,36]$, the uterus $[37,38]$, the adrenal glands [3941], the brains [42], and the retina [43-47] of mice, rats and chickens. Thus, it is clear that all the cells in various organs of various animals synthesize DNA not only in their nuclei but also in their mitochondria.

The relationship between the intramitochondrial DNA synthesis and cell cycle was formerly studied in synchronized cells and it was clarified that the intramitochondrial DNA synthesis was performed without nuclear involvement [4]. However, the relationship between the DNA synthesis and the aging of individual animals and men has not yet been clarified except a few papers recently published by Korr and associates on mouse brain [71-74]. They reported both nuclear DNA repair, measured as nuclear unscheduled DNA synthesis, and cytoplasmic DNA synthesis labeled with ${ }^{3} \mathrm{H}$-thymidine in several types of cells in brains such as pyramidal cells, Purkinje cells, granular cells, glial cells, endothelial cells, ependymal cells, epithelial cells as observed by light microscopic radioautography using paraffin sections. They observed silver grains over cytoplasm of these cells by light microscopy and maintained that it was reasonable to interpret these labeling as ${ }^{3} \mathrm{H}-\mathrm{DNA}$ outside the nuclei, which theoretically belonged to mitochondrial DNA without observing the mitochondria by electron microscopy. From the results, they concluded that distinct types of neuronal cells showed a decline of both unscheduled DNA and mitochondrial DNA syntheses with age in contrast that other cell types, glial and endothelial cells, did not show such age-related changes without counting the number of mitochondria in respective cells nor counting the labeling indices at respective aging stages. Thus, their results from the statistics obtained from the cytoplasmic grain counting seems to be not accurate without observing mitochondria directly. To the contrary, we had studied DNA synthesis in the livers of aging mice [16-29] and clearly demonstrated that the number of mitochondria in each hepatocytes, especially mononucleate hepatocytes, increased with the ages of animals from the perinatal stages to adult and senescent stages, while the number of labeled mitochondria and the labeling indices increased from the perinatal stages, reaching a maximum at postnatal day 14 , then decreased.

Our previous studies $[22,23]$ also clarified that the DNA synthesis and cell proliferation by mitosis were the most active in the nuclei of mononucleate hepatocytes at the perinatal stages in contrast that binucleate cells were less active at the perinatal stage but the number of binucleate hepatocytes increased at senescent stages and the results suggest the possibility that the mitochondria in mononucleate hepatocytes synthesized their DNA by themselves which peaked at postnatal day 14 in accordance with the proliferation of mononucleate hepatocytes while binucleate hepatocytes increased after the perinatal stage and did not divide but remained binucleate keeping many mitochondria in their cytoplasm which were more in number than mononucleate hepatocytes at the senescent stage.

Thus, our previous papers were the first which dealt with the relationship between the DNA synthesis and aging in hepatocytes of mice in vivo at various ages by means of electron microscopic radioautography observing the small dot-like silver grains, due to incorporations of ${ }^{3} \mathrm{H}$-thymidine, which exactly localized inside the mitochondria.

Later we also studied intramitochondrial DNA synthesis in adrenal cortical cells from prenatal day 19 to postnatal day $1,3,9,14$, month $1,2,6,12$ and 24 (year 2) and found that the numbers of mitochondria in 3 zones, glomerulosa, fasciculate and reticularis, increased reaching the maxima at postnatal month 2 and which kept continued until senescence up to 24 months ( 2 years). To the contrary, the numbers of labeled mitochondria and the labeling indices increased to postnatal month 2 , reaching the maxima, then decreased to month 24 [74-79]. However, it is very interesting that the new data obtained recently from the very old 2 groups at postnatal month 12 and 24 did not show any dramatic decrease as the author first expected.

The present results also revealed that an increase was observed by direct observation on mitochondria at electron microscopic level and obtaining accurate mitochondrial number and labeling indices in adrenal medullary cells in 8 groups of developing mice. There was a discrepancy between our results from the hepatocytes $[22,23]$ as well as the adrenal medullary cells at present and the results from the several types of cells in the brains by Korr et al. [70-73]. The reason for this difference might be due to the difference between the cell types (hepatocytes or adrenal cells and the brain cells) or the difference between the observation by electron microscopy, i.e., direct observation of mitochondria in our results or light microscopy, i. e., indirect observation of mitochondria without observing any mitochondria directly and misinterpretation by Korr et al. [70-73].

Anyway, the results obtained from the adrenal glands of aging mice at present should form a part of special cytochemistry [50], as well as a part of special radioautographology [51], i.e., the application of radioautography to the adrenal glands, as was recently reviewed by the present author. We expect that such special 
radioautographology and special cytochemistry should be further developed in all the organs in the future.

\section{CONCLUSIONS}

From the results obtained at present, it was concluded that almost all the cells, both adrenalin and noradrenalin cells, in the adrenal medullae of mice at various ages, from prenatal embryo day 19 to postnatal newborn, day 1,3,9 and 14 , and to postnatal month 1,2 and 6 , were labeled with silver grains showing DNA synthesis with ${ }^{3} \mathrm{H}$-thymidine in their mitochondria. Quantitative analysis on the number of mitochondria in adrenal medullary cells resulted in increases from the prenatal day to postnatal day $1,3,9,14$, and month 1,2 and 6 , reaching the maximum at postnatal day 14 to month 6. To the contrary, the numbers of labeled mitochondria with ${ }^{3} \mathrm{H}$-thymidine showing DNA synthesis and the labeling indices also increased from prenatal day 19 to postnatal day 14 , reaching the maximum at postnatal day 14 , and then decreased to month 1,2 and 6 . These results demonstrate that the number of mitochondria in adrenal cortical cells increased from perinatal stages to postnatal month 6 due to aging of animals, while the activity of mitochondrial DNA synthesis increased to postnatal day 14 , due to development and decreased to month 6 due to aging. It is interesting that the new data obtained recently from the very old groups at postnatal month 12 and 24 did not show so much decrease as the author expected.

\section{ACKNOWLEDGEMENTS}

This study was supported in part by Grant-in-Aids for Scientific Research from the Japan Society for Promotion of Sciences (No. 18924034, No. 19924204 and No. 20929003) while the author has been working at Shinshu Institute of Alternative Medicine and Welfare since 2005 up to the present time. The author is also grateful to Grant-in-Aids for Scientific Research from the Ministry of Education, Science and Culture of Japan (No. 02454564) while the author worked at Shinshu University School of Medicine (to 1996), as well as Grants for Promotion of Characteristic Research and Education from the Japan Foundation for Promotion of Private Schools (1997, 1998 1999, 2000) while the author worked at Nagano Women's Jr. College. The author thanks Dr. Kiyokazu Kametani, Technical Official, Research Center for Instrumental Analysis, Shinshu University, for his technical assistance during the course of this study.

\section{REFERENCES}

[1] Nagata T, Shibata O, Nawa T. Electron microscopic radioautographic studies of nucleic acid and protein syntheses in the liver and kidney cells of chickens and mice in tissue culture. Arch Histol Jpn 1967; 28: 540-1.

[2] Nagata T, Shibata O, Nawa T. Incorporation of tritiated thymidine into mitochondrial DNA of the liver and kidney cells of chickens and mice in tissue culture. Histochemie 1967; 10: 305-8.

[3] Nagata T. Electron microscopic dry-mounting autoradiography. In: Takeuchi T, Ogawa K, Eds. Proceedings of the $4^{\text {th }}$ International Congress on Histochemistry and Cytochemistry; Kyoto: Japan 1972; pp. 43-4.

[4] Nagata T. Radioautographic study on intramitochondrial nucleic acid synthesis: Its relationship to the cell cycle in cultivated cells. In: Takeuchi T, Ogawa K, Eds. Proceedings of the $4^{\text {th }}$ International Congress on Histochemistry and Cytochemistry; Kyoto: Japan 1972; pp. 223-4.
[5] Nagata T. Electron microscopic radioautography of intramitochondrial RNA synthesis of $\mathrm{HeLa}$ cells in culture. Histochemie 1972; 32: 163-70.

[6] Nagata T. Quantitative electron microscope radioautography of intramitochondrial nucleic acid synthesis. Acta Histochem Cytochem 1972; 5: 201-3.

[7] Nagata T. Electron microscopic radioautography of intramitochondrial nucleic acid syntheses in mammalian cells in vitro. In: Sanders JV, Goodchild DJ, Eds. Proceedings of the $8^{\text {th }}$ International Congress on Electron Microscopy; Canberra: Australia 1974; Vol. 2: pp. 346-7.

[8] Nagata T, Yamada Y, Iwadare N, Murata F. Relationship of intramitochondrial nucleic acid synthesis to the nucleoli in cultivated cells as revealed by electron microscopic radioautography. In, Nakai J, Yamada E, Eds. Proceedings of the $10^{\text {th }}$ International Congress on Anatomy; Tokyo: Japan 1975; pp. 474-5.

[9] Nagata T, Iwadare N, Murata F. Mitochondrial and nucleolar RNA synthesis as revealed by electron microscopic radioautography. In: Antenescu M, Munteneu N, Eds. Proceedings of the $5^{\text {th }}$ International Congress on Histochemistry and Cytochemistry; Bucharest: Rumania 1976; pp. 242-3.

[10] Nagata T. Electron microscopic observation of target cells previously observed by phase-contrast microscopy: Electron microscopic radioautography of laser beam irradiated cultured cells. J Clin Electron Microsc 1984; 17: 589-90.

[11] Nagata T, Murata F. Electron microscopic dry-mounting radioautography for diffusible compounds by means of ultracryotomy. Histochemistry 1977; 54: 75-82.

[12] Nagata T, Iwadare N, Murata F. Electron microscopic radioautography of nucleic acid synthesis in cultured cells treated with several carcinogens. Acta Pharmacol Toxicol 1977; 41: 64-5.

[13] Nagata T, Murata F, Yoshida K, Ohno S, Iwadare N. Whole mount radioautography of cultured cells as observed by high voltage electron microscopy. In: Yamada E, Fujita S, Eds. Proceedings of the $5^{\text {th }}$ International Conference on High Voltage Electron Microscopy; Kyoto: Japan 1977; pp. 347-50.

[14] Nagata T, Ohno S, Murata F. Electron microscopic dry-mounting radioautography for soluble compounds. Acta Pharmacol Toxicol 1977; 41: 62-3.

[15] Nagata T, Ito M, Chen S. Aging changes of DNA synthesis in the submandibular glands of mice as observed by light and electron microscopic radioautography. Ann Microsc 2000; 1: 13-22.

[16] Nagata T, Ohno S, Kawahara I, Yamabayashi S, Fujii Y, Murata F. Light and electron microscopic radioautography of nucleic acid synthesis in mitochondria and peroxisomes of rat hepatic cells during and after DEHP administration. Acta Histochem Cytochem 1979; 16: 610-1.

[17] Nagata T, Ohno S, Yoshida K, Murata F. Nucleic acid synthesis in proliferating peroxisomes of rat liver as revealed by electron microscopical radioautography. Histochem J 1982; 14: 197-204.

[18] Nagata T, Fujii Y, Usuda N. Demonstration of extranuclear nucleic acid synthesis in mammalian cells under experimental conditions by electron microscopic radioautography. In: Lentz FA, Ruele M, Eds. Proceedings of the $10^{\text {th }}$ International Congress on Electron Microscopy; Hamburg: Germany 1982; Vol. 2: pp. 305-6.

[19] Ma H, Nagata T. Studies on DNA synthesis of aging mice by means of electron microscopic radioautography. J Clin Electron Microsc 1988; 21: 335-43.

[20] Ma H, Nagata T. Electron microscopic radioautographic study of DNA synthesis in the livers of aging mice. J Clin Electron Microsc 1988; 21: 715-6.

[21] Ma H, Gao F, Sun L, Jin C, Nagata T. Electron microscopic radioautographic study on the synthesis of DNA, RNA and protein in the livers of aging mice. Med Electron Microsc 1994; 27: 34951.

[22] Nagata T. Light and electron microscopic radioautographic studies on macromolecular synthesis in amitotic hepatocytes of aging mice. Cell Mol Biol 2003; 49: 591-611.

[23] Nagata T, Ma H. Electron microscopic radioautographic study on mitochondrial DNA synthesis in hepatocytes of aging mouse. Ann Microsc 2005; 5: 4-18.

[24] Nagata T. Electron microscopic radioautographic study on protein synthesis in hepatocyte mitochondria of developing mice. Ann Microsc 2006; 6: 42-54. 
[25] Nagata T. Electron microscopic radioautographic study on macromolecular synthesis in hepatocyte mitochondria of aging mouse. J Cell Tissue Res 2007; 7: 1019-29.

[26] Nagata T. Electron microscopic radioautographic study on nucleic acids synthesis in hepatocyte mitochondria of developing mice. Trends Cell Mol Biol 2007; 2: 19-33.

[27] Nagata T. Electron microscopic radioautographic study on protein synthesis in mitochondria of binucleate hepatocytes in aging mice. Sci World J 2007; 7: 1008-23.

[28] Nagata T. Macromolecular synthesis in hepatocyte mitochondria of aging mice as revealed by electron microscopic radioautography. I. Nucleic acid synthesis. In: Vilas AM, Alvarez JD, Eds. Modern Research and Educational Topics in Microscopy. Spain: Formatex, Badajoz 2007; Vol. 1: pp. 245-58.

[29] Nagata T. Aging changes of macromolecular synthesis in the mitochondria of mouse hepatocytes as revealed by microscopic radioautography. Ann Rev Biomed Sci 2007; 9: 30-6.

[30] Nagata T. Radiolabeling of soluble and insoluble compounds as demonstrated by light and electron microscopy. In: Wegmann RJ, Wegmann MA, Eds. Recent Advances in Cellular and Molecular Biology. Leuven, Belgium: Peters Press 1992; Vol. 6: pp. 9-21.

[31] Nagata T, Usuda N, Ma H. Electron microscopic radioautography of nucleic acid synthesis in pancreatic acinar cells of prenatal and postnatal aging mice. In: Shimazu S, Fukami A, Eds. Proceedings of the $11^{\text {th }}$ International Congress on Electron Microscopy; Kyoto: Japan 1986; Vol. 3: pp. 2281-2.

[32] Sun L, Gao F, Jin C, Nagata T. DNA synthesis in the trachea of aging mice by light and electron microscopic radioautography. Acta Histochem Cytochem 1997; 30: 211-20.

[33] Nagata T, Sun L. Electron microscopic radioautographic study on mitochondrial DNA and RNA syntheses in pulmonary cells of aging mice. Ann Microsc 2007; 7: 36-59.

[34] Hanai T, Nagata T. Electron microscopic radioautographic study on nucleic acid synthesis in perinatal mouse kidney tissue. Med Electron Microsc 1994; 27: 355-7.

[35] Gao F, Ma H, Sun L, Jin C, Nagata T. Electron microscopic radioautographic study on the nucleic acid and protein synthesis in the aging mouse testis. Med Electron Microsc 1994; 27: 360-2.

[36] Gao F, Chen S, Sun L, Kang W, Wang Z, Nagata T. Radioautographic study of the macromolecular synthesis of Leydig cells in aging mouse testis. Cell Mol Biol 1995; 41: 145-50.

[37] Yamada AT, Nagata T. Light and electron microscopic radioautography of DNA synthesis in the endometria of pregnant ovariectomized mice during activation of implantation window. Cell Mol Biol 1992; 38: 763-74.

[38] Yamada AT, Nagata T. Light and electron microscopic radioautographic studies on the RNA synthesis of peri-implanting pregnant mouse uterus during activation of receptivity for blastocyst implantation. Cell Mol Biol 1993; 39: 221-33.

[39] Ito M, Nagata T. Electron microscopic radioautographic study on DNA synthesis and the ultrastructure of the adrenal gland in aging mice. Med Electron Microsc 1996; 29: 145-52.

[40] Ito M. A dioautographic studies on aging changes of DNA synthesis and the ultrastructural development of mouse adrenal gland. Cell Mol Biol 1996; 42: 279-92.

[41] Nagata T. Electron microscopic radioautographic study on mitochondrial DNA synthesis in adrenal cortical cells of developing mice. J Cell Tisue Res 2008; 8: 1303-12.

[42] Cui H, Gao F, Ma H, Nagata T. Study on DNA synthesis of cellular elements in the cerebella of aging mice by light and electron microscopic radioautography. In: Quenyuan XU, Shaoyauan WU, Eds. Proceedings of the $4^{\text {th }}$ China-Japan Joint Histochemistry and Cytochemistry Symposium. Chongqing, China: Chongqing Publishing House 1996; pp. 111-2.

[43] Gunarso W. Radioautographic studies on the nucleic acid synthesis in the retina of chicken embryo II. Electron microscopic radioautography. Shinshu Med J 1984; 32: 241-8.

[44] Gunarso W, Gao F, Cui H, Ma H, Nagata T. A light and electron microscopic radioautographic study on RNA synthesis in the retina of chick embryo. Acta Histochem 1996; 98: 300-22.

[45] Gunarso W, Gao F, Nagata T. Development and DNA synthesis in the retina of chick embryo observed by light and electron microscopic radioautography. Cell Mol Biol 1997; 43: 189-201.

[46] Kong Y, Nagata T. Electron microscopic radioautographic study on nucleic acid synthesis of perinatal mouse retina. Med Electron Microsc 1994; 27: 366-8.
[47] Nagata T. Aging changes of macromolecular synthesis in the avian and mammalian eyes as revealed by microscopic radioautography. Ann Rev Biomed Sci 2006; 8: 33-67.

[48] Nagata T. Electron microscopic radioautographic study on mitochondrial DNA synthesis in adrenocortical cells of mice in aging and senescence. J Cell Tissue Res 2008; 8: 1617-28.

[49] Nagata T. Electron microscopic radioautographic study on mitochondrial DNA synthesis in adrenal medullary cells of developing and aging mice. J Cell Tissue Res 2009; 9: 1793-802.

[50] Nagata T. Special Cytochemistry in Cell Biology. In: Jeon KW, Ed. International Review on Cytology, New York, USA: Academic Press 2001; Vol. 211: pp. 33-151.

[51] Nagata T. Radioautographology General and Special. In: Graumann W, Ed. Progress in Histochemistry and Cytochemistry. Jena, Germany: Urban \& Fischer 2002; Vol. 37(2): pp. 57-226.

[52] Nagata T. Techniques and application of electron microscopic radioautography. J Electron Microsc 1996; 45: 258-74.

[53] Nagata T. Techniques and application of microscopic radioautography. Histol Histopathol 1997; 12: 1091-124.

[54] Nass S, Nass MMK. Intramitochondrial fibers with DNA characteristics. I. Fixation and electron staining reactions. II. Enzymatic and other hydrolytic treatments. J Cell Biol 1963; 19: 593-629.

[55] Gibor A, Granick S. Plastids and mitochondria: Inheritable system. Science 1964; 145: 890-7.

[56] Gahan PB, Chayen J. Cytoplasmic deoxyribonucleic acid. Int Rev Cytol 1965; 18: 223-47.

[57] Nass MMK. The circularity of mitochondrial DNA. Proc Natl Acad Sci USA 1966; 56: 1215-22.

[58] van Bruggen EFJ, Borst P, Ruttenberg GJCM, Gruber M, Kroon AM. Circular mitochondrial DNA. Biochim Biophys Acta 1966; 119: 437-9.

[59] Sinclair JH, Stevens BJ. Circular DNA filaments from mouse mitochondria. Proc Natl Acad Sci USA 1966; 56: 508-14.

[60] Schatz G. Biogenesis of mitochondria. In: Racker E, Ed. Membranes of Mitochondria and Chloroplasts. New York, USA: Van Nostrand-Reinhold 1970; pp. 251-314.

[61] Guttes E, Guttes S. Thymidine incorporation by mitochondria in Physarum polycephalum. Science 1964; 145: 1057-8.

[62] Schuster FL. A deoxyribose nucleic acid component in mitochondria of Didymium nigirpes, a slime mold. Exp Cell Res 1965; 39: 329-45.

[63] Stone GE, Miller OL Jr. A stable mitochondrial DNA in Tetrahymena puriformis. Exp Zool 1965; 159: 33-7.

[64] Chévremont M. Cytoplasmic deoxyribonucleic acids: their mitochondrial localization and synthesis in somatic cells under experimental conditions and during the normal cell cycle in relation to the preparation for mitosis. In: Harris RJC, Ed. Cell Growth and Cell Division. Symposia of the International Society for Cell Biology. New York, USA: Academic Press 1963; Vol. 2: pp. $323-$ 33.

[65] Salpeter MM, Bachmann L, Salpeter EE. Resolution in electron microscope radioautography. J. Cell Biol 1969; 44: 1-20.

[66] Nadler NJ. The interpretation of grain counts in electron microscope radioautography. J Cell Biol 1971; 49: 377-82.

[67] Uchida K, Mizuhira V. Electron microscope autoradiography with special reference to the problem of resolution. Arch Histol Jpn 1971; 31: 291-320.

[68] Murata F, Yoshida K, Ohno S, Nagata T. Electron microscopic radioautography using a combination of phenidon developer and domestic emulsion. Acta Histochem Cytochem 1979; 12: 443-50.

[69] Nagata T. Electron microscopic observation of target cells previously observed by phase-contrast microscopy: electron microscopic radioautography of laser beam irradiated cultured cells. J Clin Electron Microsc 1984; 17: 589-90.

[70] Korr H, Phillipi V, Helg C, Schiefer J, Graeber MB, Kreutzberg GW. Unscheduled DNA synthesis and mitochondrial DNA synthetic rate following injuring of the facial nerve. Acta Neuropathol 1997; 94: 557-66.

[71] Korr H, Kurz C, Seidler TO, Sommer D, Schmitz C. Mitochondrial DNA synthesis studied autoradiographically in various cell types in vivo. Braz J Med Biol Res 1998; 31: 289-98.

[72] Schmitz C, Axmacher B, Zunker U, Korr H. Age related changes of DNA repair and mitochondrial DNA synthesis in the mouse brain. Acta Neuropathol 1999; 97: 71-81. 
[73] Schmitz C, Materne S, Korr H. Cell-type-specific differences in age-related changes of DNA repair in the mouse brain - Molecular basis for a new approach to understand the selective neuronal vulnerability in Alzheimer's disease. J Alzheimers Dis 1999; 1: 387-407.

[74] Nagata T. Electron microscopic radioautographic study on intramitochondrial DNA synthesis in adrenal cortical cells of developing mice. J Cell Tissue Res 2008; 8: 1303-12.

[75] Nagata T. Electron microscopic radioautographic study on mitochondrial DNA synthesis in adreno-cortical cells of developing mice. Ann Microsc 2008; 8: 22-35.
[76] Nagata T. Electron microscopic radioautographic study on mitochondrial DNA synthesis in adrenal cortical cells of developing and aging mice. Sci World J 2008; 8: 683-97.

[77] Nagata T. Electron microscopic radioautographic study on mitochondrial DNA synthesis in adrenocortical cells of aging and senescent mice. J Cell Tissue Res 2008; 8: 1499-510.

[78] Nagata T. Electron microscopic radioautographic study on mitochondrial DNA synthesis in adrenocortical cells of developing and aging mice. J Chin Clin Med 2008; 3: 609-20.

[79] Nagata T. Recent studies on macromolecular synthesis labeled with ${ }^{3} \mathrm{H}$-thymidine in various organs as revealed by electron microscopic radioautography. Curr Radiopharm 2009; 2: 118-28.

(C) Tetsuji Nagata; Licensee Bentham Open.

This is an open access article licensed under the terms of the Creative Commons Attribution Non-Commercial License (http://creativecommons.org/licenses/by-nc/ $3.0 /$ ) which permits unrestricted, non-commercial use, distribution and reproduction in any medium, provided the work is properly cited. 